\title{
WATER RESOURCES AND TOURISM DEVELOPMENT IN ESTRELA GEOPARK TERRITORY: MEANING AND CONTRIBUTIONS OF FLUVIAL BEACHES TO VALORISE THE DESTINATION
}

Gonçalo Fernandes ${ }^{1}$, Emanuel de Castro², Hugo Gomes ${ }^{3}$

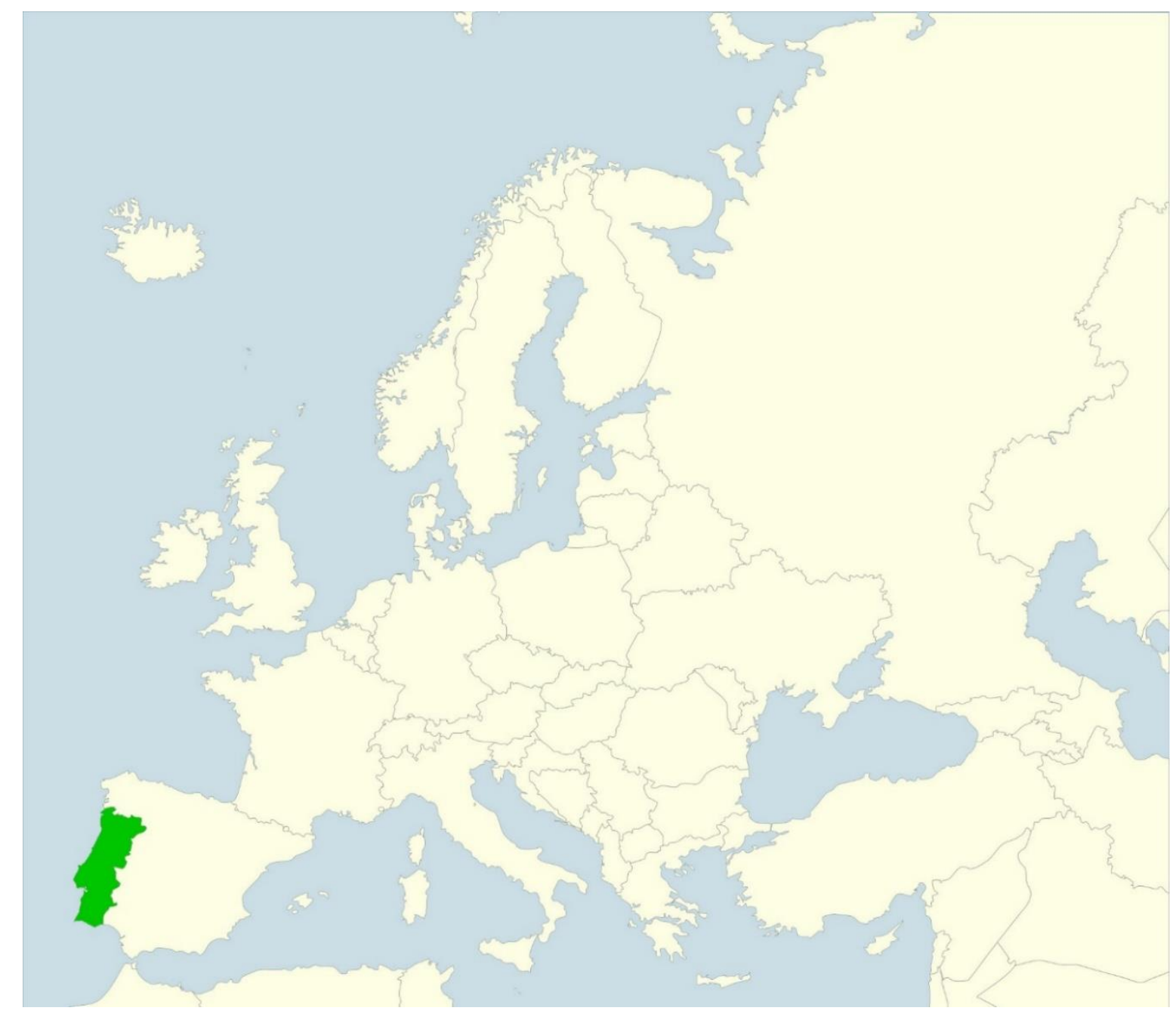

${ }^{1}$ Goncąlo Poeta Fernandes, Polytechnic Institute of Guarda, Portugal; e-mail: goncalopoeta@ipg.pt; ORCID: 00000003-1278-0369

${ }^{2}$ Emanuel de Castro, Geopark Estrela, Torre da Serra da Estrela, Portugal; e-mail: emanuelcastro@geoparkestrela.pt; ORCID: 0000-0003-1097-0863

3 Hugo Gomes, Geopark Estrela, Torre da Serra da Estrela, Portugal; e-mail: hugogomes@geoparkestrela.pt; ORCID: 0000-0003-0665-9116 
Abstract: Rural areas and in particular mountain territories have been experiencing an increasing appreciation of natural and heritage resources and their use for recreational and leisure activities, boosting tourism development and generating renewed functions with economic and social impact. Inland waters are becoming increasingly important for leisure and tourism, with many activities associated and many users seeking for them. Fluvial beaches represent leisure facilities for rural communities, allowing people and visitors access to aquatic spaces for leisure, sport and entertainment, creating conditions for enjoying nature and water resources, particularly during the summer period. The supply of surface water resources - rivers, lakes and canals - in the territory of the Estrela Geopark in Portugal, represent a tourist potential for this mountain region. They qualify the offer and constitute recreational attractions appreciated by the community and tourists, generating social well-being and fostering new services. There is a growing demand for these spaces, allowing the upgrading of fluvial areas, generating new features and enhancing the image of the destination Serra da estrela. The greater part of this equipment is operated by public entities linked to local administration, thus benefiting from public investment and support. There is a strong perception of its importance in attracting tourists, in improving the quality of life of the local population and in the opportunity to expand trade and service activities. Also in the image of the community, and their self-esteem is perceived, the importance of river beaches and consequently the disclosure that they associate, in terms of environmental quality, heritage value, and space of tranquillity.

Keywords: Fluvial beaches, Inland waters, Tourism, Leisure, Mountain, Estrela Geopark

\section{Introduction}

Rural areas have been experienced in the last two decades an appreciation of their natural and heritage resources and their growing use for recreational and leisure activities, boosting tourism development and generating renewed functions with economic and social impact. In this context, inland waters acquire increasing importance for leisure and tourism, and the activities associated with them and the investments promoted for their qualification are diverse.

The local populations have been promoting the valorisation of the touristic activities supported in the fluvial environments and foster the diverse uses that the water resources support, in a model of territorial promotion and well-being, promoting interventions and alterations that allow to receive these activities safely and with consequent concern for environmental preservation.

At the same time, benefits are perceived as a result of the expansion of services and commercialization of local products that generate economic effects and bring value to the destination. Note that it is the quality of the waters, preserving the environment, the maintenance of the characteristics of river ecosystems, and their own rurality that support the value of these spaces in tourism. River and fluvial beaches represent leisure facilities for rural communities, allowing local people and visitors access to aquatic spaces for leisure, sport and entertainment, creating conditions for enjoying nature and water resources, particularly during the summer period.

The territory of the Serra da Estrela, corresponding to the set of 9 municipalities that make up the Estrela Geopark, contains a group of relevant water resources, where the main Portuguese rivers originate, a diversity of lakes and dams of different origin and where they are accounted for 2019 a set of 11 certified fluvial beaches. This study aims to highlight the importance of surface water resources for inland tourism and to identify and analyze the characteristics of the fluvial beaches of the Estrela Geopark territory, the services and equipment to support leisure and recreation, and the management methods, in a touristic value and sustainability of inland water uses. An electronic survey was applied to fluvial beaches concessionaires/managers and direct contacts were developed to obtain information on the functioning of the beaches, their 
characteristics, and functional valences and to promote the assessment of their importance in terms of touristic destination and value to local communities.

In this context, fall into water resources in tourism development, enhancing its recreational and economic importance in rural areas of the inland of Portugal. It establishes a territorial approach to the Serra da Estrela destination, seeking to analyze the fluvial beaches and their current meaning for tourism and leisure and simultaneously the perception of the value they generate for local communities.

The study aims to develop the importance of river waters for tourist activities and their importance in inland regions. The Geopark Star and the classified river beaches are summarized, promoting an applied study on the forms of management, its organization, and its importance for the local communities. An inquiry has been developed which has allowed us to assess the form of organisation and operation of the waterways and to assess their importance, from the managers/concessionaires, their importance for the consolidation of the tourist image of the region and the promotion of social well-being.

\section{Water resources and tourism development}

The management of water resources is a complex issue of collective interest and relevance to the environment, especially when the water sources such as rivers, lakes, reservoirs, canals, marshes, and other aquifers present concern conditions due to the uses and functions that support. They require actions and forms of control that ensure the preservation of their ecosystems and the quality of their water (Peixoto, 2016; Folgado Fernandez et al., 2019). They are public goods and their management should value and protect the interests of the local communities established there and of the economic and social activities developed. Over time, there has been an increase in water use needs, both in quantity and quality, as a result of population growth and expansion of activities and consumption, which require more water resources and increased control over uses and functions developed (Prideaux et al., 2009).

The relationship between water and tourism is characterized by a double understanding of this element: as a precious resource and as an attraction. Given that water is a valuable and scarce resource, research should focus on identifying practical and business initiatives through which water-based tourism can be developed without compromising the quality and availability of water resources (Brito-Henriques, 2010; Garcia Gonzalez, 2014). In this sense, the relationship between water and tourism is focused on sustainability. On the other hand, as a tourism attraction, water represents a resource with strong potential to attract tourists (Grössling et al., 2015; Cole \& Ferguson, 2015). In this scope, fluvial tourism contributes significantly to local development. Incentives from local authorities and institutional organizations have favored the emergence of endogenous entrepreneurial strategies (World Tourism Organization, 2016; Violier, 1993).

The growing interest in the enhancement and exploitation of inland water resources for activities not related to water supply to communities, industry and agriculture, has been expressing itself in recent decades. Accompanying the growth of leisure and tourism experiences in rural areas, the appreciation of riparian ecosystems is a concern of local entities in the qualification of these resources and in generating new opportunities for local communities (Garcia Gonzales, 2004). The changing sensitivity to water and its importance for health and leisure signal the potential for the development of a social conscience capable of generating new business opportunities that can create value for interior geographic territories with new roles and users. This emerging water culture emphasizes the importance of achieving a harmonious, quality, and sustainable relationship with this element (Folgado Fernández et al., 2019).

In Portugal, the importance of water for leisure and tourism and its development has been analyzed and the target of studies from different perspectives and supported by projects that seek understandings and conceptualizations with increasing interest. (Cavaco \& Simões 1998; Costa 2010, Sarmento \& Lousada, 2010; Moreira \& Santos, 2010, 2016; Santos, 2012, 2016, Moreira, 2012, 2016, 2018).

In terms of national fluvial tourism, the rivers, lakes, and reservoirs stand out for their significance as spaces for the reception and development of sports, recreational and recreational activities. 
There is an investment in the development of infrastructures and equipment that allow the expansion of tourism and leisure and the creation of the necessary conditions for a qualified performance as recreational spaces, entertainment, and differentiated tourist activities.

In this context, fluvial beaches arise from the reuse of water lines/surface of a river channel or reservoir (dam, reservoir or lagoon), constituting a form of creation of a recreational and sporting space, generating a leisure structure for the local communities and an element of tourist attraction (Cole \& Ferguson, 2015; Santos, 2016). Its creation requires the development of studies and the evaluation of the appropriate functions, so as not to disturb the natural environment and to create the necessary access and security conditions for its operation. A significant part of the environmental changes result from the pollutant discharges and inability to assimilate them by the water resource, with higher incidence in the summer period, compared to the natural water regime and consequent reduction of flow, increasing the density of pollutants, disturbing and endangering the species and their ecosystems (Cole \& Ferguson, 2015; Ferreira \& Guerreiro de Brito, 2009). There is a growing concern between different uses of water resources and the maintenance of species and ecosystems, considering the resulting changes and major conflicts in the interface between use and environmental protection (Ferreira \& Guerreiro de Brito, 2009; Hall \& Härkönen, 2006).

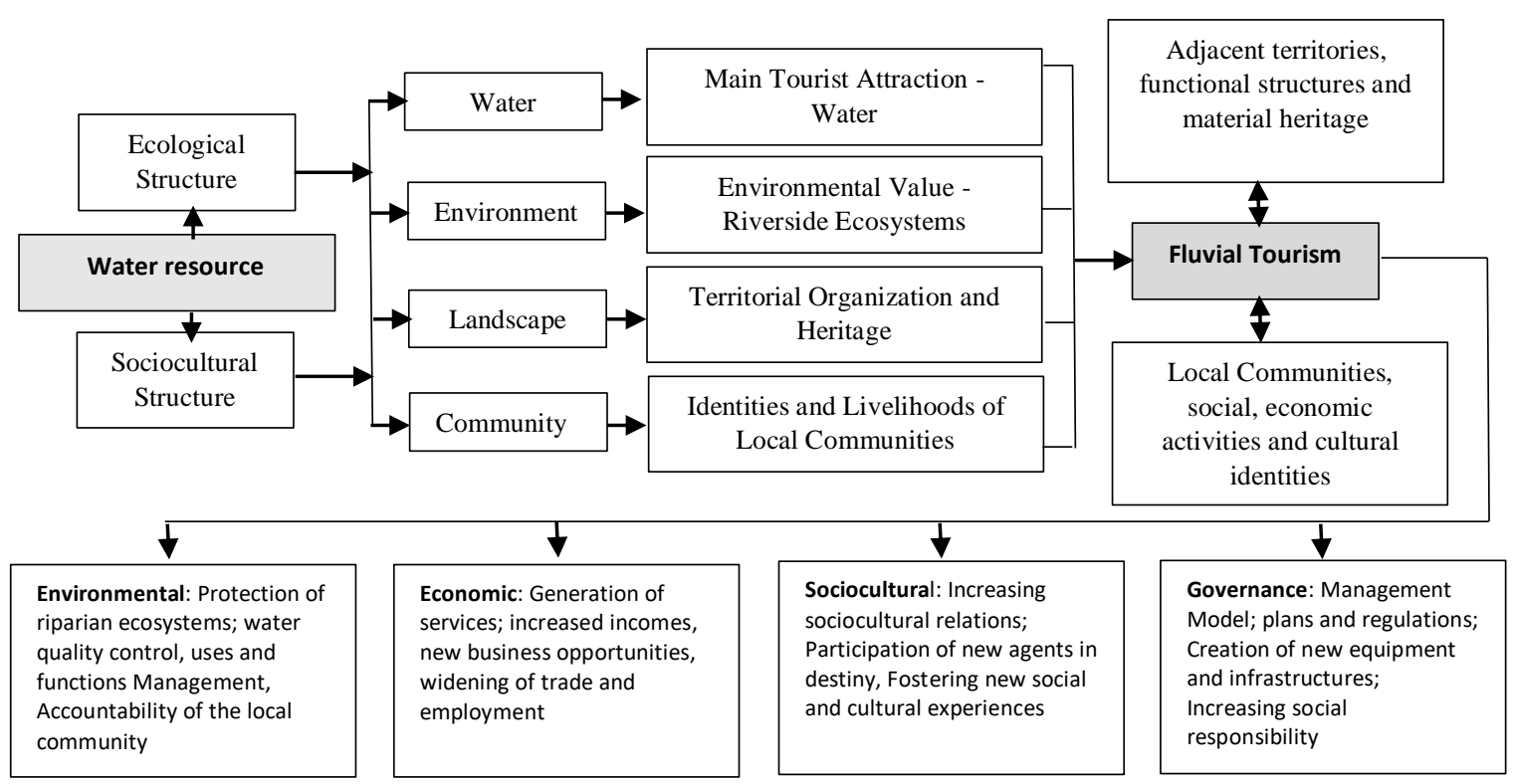

Fig 1. Relational structure of fluvial tourism with the territory. Source: Authors elaboration

Leisure, recreational, sports, or competitive activities may take place in these spaces, depending on the geomorphological conditions, the characteristics of the existing riparian ecosystems, the size of the water bodies, and the infrastructures developed. Due to the environmental value of these resources and the ecosystems that represent a latent fragility that requires the proper management and adaptation of spaces to different uses and functions, without compromising the sustainability of ecosystems and user's safety. According to Moreira, C. (2018), the diversity and sometimes even conflicting coexistence of socio-economic activities with different interests poses new challenges to the management of rivers and inland waters (Figure 1). Today's dynamics are unprecedented, as rivers have never been the subject of such diverse and intense interests and demand as they are. Its impact on waters and surrounding areas increasingly implies greater control, qualification, and regulation, capable of optimizing and adjusting uses and generating social well-begin. (Moreira \& Santos, 2016; Vaz, 2008).

There is a dependent and consequent relationship between the resource and the territory and the surroundings, in particular with the margins (river or reservoir margin) where the impact of human action is exerted on a large scale by the development of investments in equipments and infrastructures, changes in natural conditions, new uses and associated services. Thus, and especially in the summer period, conditions and means are required to safeguard environmental 
values and enable practices that are adjusted to existing conditions (Moreira et al., 2002; Peixoto, 2016).

This relationship between bank and river resources (rivers, pond, reservoir, canal, among others) requires the creation of appropriate conditions that guarantee safe access, the installation of conditions and means of support, and sustainable management. River beaches can, therefore, be considered, especially in the interior and rural areas, a new specific segment of the tourist market. They can combine several tourist products, as a result of the specific characteristics they present, the purpose they are intended for, the activities they allow to develop, and the environment in which they operate (Gouveia, 2009, p.32).

The concept of a river beach as a bathing area is relatively recent, but it has been a long time since men have enjoyed the rivers and its banks for recreation and leisure (family picnics, river bathing, fishing, boating, etc.). River beaches can thus be considered, especially in the inland and rural areas, a tourism segment, which combines beach tourism with the three strategic tourism products for the interior areas, namely cultural and landscape touring,

The main feature of fluvial tourism is water, which is one of the most popular natural settings for rest and recreation. The activities that can be practiced in fluvial beaches, considering the integrated set of water-bank resource, the following should be considered: swimming, diving, sport fishing, rowing, canoeing/sailing, river cruises, fish watching, thermalism, hiking, among others. In the context of river tourism, we are in a territorialized combination of water, as the main attraction, of the environmental value of riparian ecosystems, as a natural setting, of heritage groups, as identity and representation of history, culture, knowledge and traditions, as spaces of life and relationship from local communities.

The approaches generated to the water resources and the territories that support them, promote their knowledge and recognition of their potentialities and problems, fostering more responsible attitudes towards the forms of water appropriation and associated systems. Riverside area issues and settlements in the surrounding areas are important where the locals around the riverside area involved directly and under the influence of these activities. The provision of support facilities serves to improve the quality of life of residents based on economy (Poedjiotami, 2008). It is worth highlighting the sets of heritage elements that over time the communities and their activities have been developing, currently assuming an ecocultural value, for their meaning and representation of past practices, such as bridges, former irrigation channels, enclosures, mills, tusks of water, military monuments, terraces among others. The connection between the community, territory, and tourism is a fundamental process for the promotion of tourism in rural areas (Garcia Gonzales, 2004; Hall \& Harkonen, 2006). River resources and the heritage associated with them, along their banks or in the surrounding villages, linked to economic activities, mobility, or water management structures, are simultaneously with riverside ecosystems, elements with the potential to affect tourism and service development.

The changing sensitivity to water and its importance for health and leisure signal the potential for the development of a social conscience capable of generating new business opportunities that can create value for interior geographic territories with new roles and users. This emerging water culture emphasizes the importance of achieving a harmonious, quality, and sustainable relationship with this element. (Folgado Fernandez et al., 2019). The 2030 Agenda for Sustainable Development, adopted in 2015 by all countries of the United Nations, recognises the importance of water and its relevance for the well-being of humanity. The water is very important for various ecosystems and communities, indicated to us its Sustainable Development Goals (SDG), in particular in its Goal 6 - Ensure availability and sustainable management of water and sanitation for all -, the concern among other critical aspects for protection and restore water-related ecosystems, including mountains, forests, wetlands, rivers, aquifers and lakes, and improve water quality by reducing pollution, eliminating dumping and minimizing release of hazardous chemicals and materials, halving the proportion of untreated wastewater and substantially increasing recycling and safe reuse globally.

At the level of the river beaches, it seems to be fundamental to achieve a balance between the users of these spaces, the activities that are developed there and the socio-cultural characteristics, allowing the enjoyment, preservation of natural values and continuity of traditional 
functions, in order to be possible to generate a truly sustainable tourism. In the light of current interests, special attention must be paid to the relationship between aquatic environments and the supply that can be found in inland waters through their lifestyles, their histories, their knowhow and their landscapes (Moreira \& Santos, 2016)

In the inland waters, in particular those where the touristic attraction is growing and there are interventions to create support services and equipment, means of access and security and management actions, require actions by local entities that enable the enhancement and qualification of these spaces for new uses and functions, matching the interests of local communities and widening demand.

It should be noted that freshwater has been neglected as a valuable space for leisure and tourism activities, considering its diversity and associated potentialities, which are factors that enhance tourism supply and the creation of associated services. Moreira \& Santos (2016) note that in Portugal, it is in the 90 s of the twentieth century in the lakes, dam and rivers intensify and diversify the secondary uses, emerging use for leisure and tourism practices, allowed in some cases, the navigability of the water lines for commercial and tourist purposes and the enjoyment of associated heritage.

In Portugal, a new framework for the legal protection of water resources was established with the entry into force of the Water Law, with the approval of a new legal regime for the use of water resources, as determined by this law and by the water resources ownership law (approved by Law No. 58/2005), establishing a framework for Community action in the field of water policy. The main objective was to create a framework for the protection of not only inland surface waters but also transitional waters, coastal waters and groundwater, the regime for the protection of public water reservoirs, and the lagoons or lakes of public waters. (MA, 1997; Moreira, 2011).

The measures designated in the POA (Operational Programme for the Environment) as "conservation and enhancement of natural heritage and improvement of environmental quality" included "regularization and planning of water lines and other natural areas" where projects for the construction and enhancement of river beaches and recovery, regularization and river course and river banks planning were approved. Investments made in the protection of water resources have improved the quality of Portuguese watercourses, thus enhancing their banks for bathing use (Goldstein, S., 2011; LaVanchy, 2017).

According to Goldstein (2011) and Jennings (2007), the development of river beaches was accomplished through the creation of access, parking, support structures (such as snack bar, kiosks selling food and beverages, first aid, grill and camping areas), surveillance of beaches by lifeguard, signage of uses, among others, enhancing the process of sustainable development of regions with good tourism potential.

\section{Methodology}

This research seeks to characterize the classified river beaches in the territory of Estrela Geopark, highlighting their potential to enhance this destination in terms of generating attractiveness and promoting well being within local communities. For this purpose, an electronic survey was developed directed to the entities that manage these equipments and promoted fieldwork, to register how the beaches were organized, the conditions of access, the services implemented, and the form of signage and information provided. The survey was applied to all the entities that manage river beaches, classified in the territory (the whole universe corresponding to 11 classified beaches in 2019), being sent the respective access link via email and then contacted by telephone to raise awareness of the completion and clarification of doubts. The procedure began in September 2019 and the collection was completed in October. This period at the end of the bathing season allowed us to obtain more qualified information, given all the experience during the summer months in the operation of the river beaches. The visits to the beaches made it possible to measure and validate the information collected, as well as to understand with the people responsible for the contributions of these equipments to the destination Serra da Estrela. Through the surveys, we tried to assess aspects related to the form of governance/management, identify the activities allowed and conditions established, the ways of 
using the bathing area and adjacent spaces, inquiring about the importance of this equipment in terms of valuing the destination and promoting the welfare of communities. Thus, we tried to evaluate the perception of the effects generated by the fluvial beaches in the tourist attraction and valorization of this mountain destination (Classified by UNESCO in 2019), in the stimulation of the local economic development, in the valorization of the water resources and the image of the community and its self-esteem. The data collected were analyzed quantitatively and qualitatively, allowing the establishment of a reference framework on the supply of fluvial beaches classified in the Geopark territory, the identification of contributions to the valorisation of tourism and leisure activities and the perception of their importance as equipment to promote the image of the destination and its effects on communities. Illustrative tables and charts were developed, allowing for the systematisation of information and the establishment of analyses on existing supply and impacts on communities.

\section{Estrela geopark tourist destination and the offer of river beaches}

The Estrela Geopark corresponds to a mountainous territory, which integrates the main mountain of Portugal (composed territorially by the municipalities of Guarda, Seia, Gouveia, Celorico da Beira, Fornos de Algodres, Manteigas, Belmonte, Covilhã and Oliveira do Hospital, encompassing an area of 2,737.72 $\mathrm{km}^{2}$ and housing 171,668 inhabitants) have the mission to contribute to the protection, enhancement of the natural and cultural heritage (Figure 2). The diversity of glacial vestiges, the wealth of its patrimony, and the characteristics of its landscape make a unique geography. It will promote the perspective of further development and dissemination of scientific knowledge, promoting tourism and sustainable development of the territory. Parallel to the tourism valorization, educational/pedagogical contexts are developed, as well as the scientific deepening, given the natural laboratory that these spaces contain, fostering new interests, new audiences, and demands.
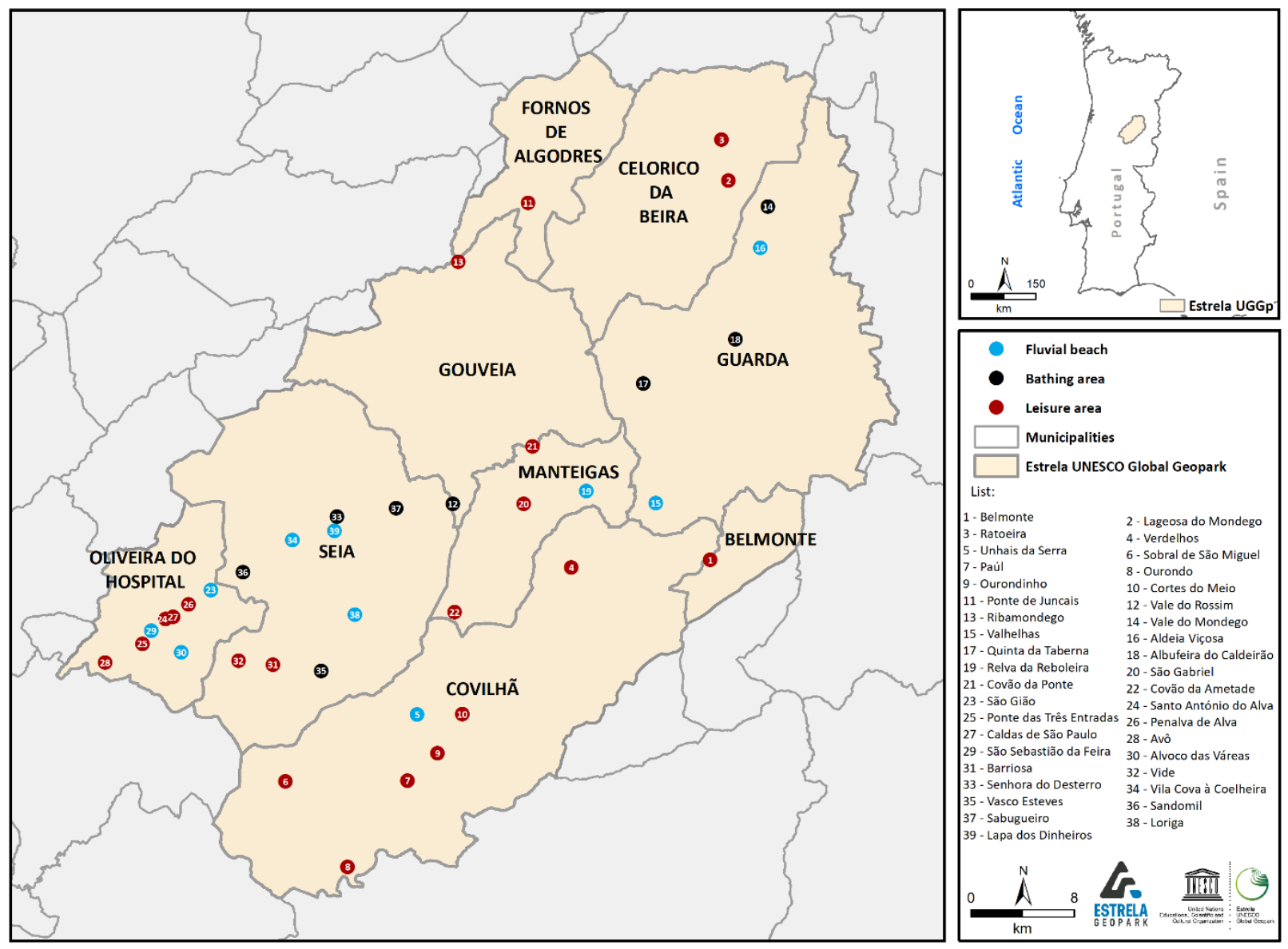

Fig 2. Location and identification of fluvial beaches and balnear areas in estrela geopark territory. Source: AGE improved by the authors 
Tourism in its relationship with the territory and the transformations operated, transmit the meaning of tourist destination, promoting its resources to establish themselves as products, which are associated with services and generate features for your enjoyment. The forms of ownership should be increasingly carefully and properly planned to ensure their best use and sustainability.

As mentioned, in Portugal, only in the last three decades, they are beginning to explore the no marine aquatic environments as a resource, product, and tourist attraction. The appreciation given to water resources at the national level dates back to the 90 s of the twentieth century, being in a phase of growing development and appreciation by tourists (Moreira \& Santos, 2016). The enhancement of rivers, canals, and dams gains significance as an alternative to coastal aquatic environments or swimming pools, promoting natural values, rurality, and the extension of recreational and sporting practices in the inland.

Sustainable tourism development in rural areas must take into account the culture and characteristics of the local community, the landscape and habitats, the rural economy and its heritage, so that the tourism offer promotes unique and differentiated experiences that guarantee continuity associated services and broaden the diversification of the rural.

Rodrigues \& Rodrigues (2007), considers that to develop a successful rural product, it is necessary to have:

- Attractions: natural or man-made being part of the community's identity;

- Promotion: marketing a destination and its attractions oriented to potential demand;

- Tourist infrastructure: accessibility, water and electricity services,

- Access and parking: signs and support infrastructures;

- Services: accommodation, restaurants, existing retail businesses to meet the needs of tourists;

- Hospitality: the diversity of accommodation and the way tourists are treated by both residents and staff of the tourist and hotel companies.

Taking into account the constant and growing competitiveness, it is essential to open to new markets and to invest in non-mass tourism exceptional products that focus on quality and differentiation. The optimization of endogenous resources available, both locally and regionally, combining services and territorial integration, was a fundamental strategy for the inland regions.

The appreciation of the water resources of the Estrela Geoparque territory, due to their diversity, environmental value, landscape, and qualifications operated, allow creating conditions for the creation of high-quality bathing spaces. In this way, leisure practices are enhanced with the local communities and at the same time attracting visitors, enhancing the Serra da Estrela tourist destination, and the creation of support services. In the Estrela Geopark territory, we can count globally a set of 38 recreation and recreation spaces supported in inland waters, which can be differentiated in bathing areas and leisure areas.

The identification of inland bathing waters and the classification of fluvial and lacustrine beaches as bathing beaches in the continental territory is defined for each year by ordinance of the competent Ministry (Law No. 44/2004 of 19 August), which identifies each beach is suitable for bathing and its bathing season (period, fixed annually by administrative determination of the competent authority, during which the obligation to guarantee the assistance to bathers is in force). Recreational and leisure bathing areas are not considered classified beaches, according to Ordinance No. 178/2013, so their use, at the level of bathing, is the sole responsibility of the users. These areas are not monitored and the quality of their waters is not assigned to any classification by the Portuguese Environment Agency, IP.

The fluvial beaches of the Estrela Geopark territory (a total of 11) classified in 2019 (Ordinance No. 141/2019 of 14 May), are divided into 6 municipalities, being in the municipalities of Seia and Oliveira do Hospital, where it has the highest expression (Table 1). 
Tab 1. Location of river beaches, bathing areas and recreation areas in the territory Estrela geopark. Source: Portaria $n .^{\circ} 141 / 2019$ de 14 de maio (DR, $1 .^{a}$ série - N. ${ }^{\circ}$ 92) and inventariatio AGE (Associação Geopark Estrela)

\begin{tabular}{l|l|c|c|c|}
\hline Municipalities & Fluvial beach & Bathing areas & $\begin{array}{c}\text { Recreation } \\
\text { area }\end{array}$ & Total \\
\hline Belmonte & & & 1 & 1 \\
\hline Celorico da Beira & & & 2 & 2 \\
\hline Covilhã & 1 & & 6 & 7 \\
\hline Fornos de Algodres & & & 1 & 1 \\
\hline Guarda & 2 & 3 & & 5 \\
\hline Gouveia & & 1 & 1 & 2 \\
\hline Manteigas & 1 & & 3 & 4 \\
\hline Oliveira do Hospital & 4 & & 5 & 8 \\
\hline Seia & 3 & 4 & 2 & 9 \\
\hline Total & 11 & 8 & 21 & 41 \\
\hline
\end{tabular}

It should be noted that the greater the number of river beaches and swimmers who frequent them, the greater requirement for the management and control of activities practiced in water bodies and associated equipments. In this context, the responsibility of public agents to monitor and manage these areas is crucial, keeping the health risk low in these recreation areas (Goldstein, 2011).

Tab 2. Location and designation of 2019 certified river beaches in Estrela geopark territory. Source: Portaria $n .^{\circ} 141 / 2019$ de 14 de maio (DR, $1 .^{a}$ série $-N .^{\circ}$ 92)

\begin{tabular}{|lcl|} 
Municipalities & Fluvial beach & \multicolumn{1}{c|}{ Designation } \\
\hline Belmonte & & \\
\hline Celorico da Beira & 1 & Unhais da Serra \\
\hline Covilhã & 2 & Valhelhas; Aldeia Viçosa \\
\hline Fornos de Algodres & 1 & Relva da Reboleira \\
\hline Guarda & 4 & $\begin{array}{l}\text { São Gião; São sebastião da Faia; Alvoco da Várzeas } \\
\text { e Avô }\end{array}$ \\
\hline Gouveia & & \begin{tabular}{l} 
Vila Cova à Coelheira, Loriga, Lapa dos Dinheiros; \\
\hline Manteigas
\end{tabular} \\
\hline Oliveira do Hospital & 3 & \\
\hline Seia & 11 & \\
\hline Total & & \\
\hline
\end{tabular}

Of the 11 existing fluvial beaches (Table 2), most of them are managed by public entities, namely parish councils, which represent $75 \%$ of the forms of management, with the remainders being municipalities and one beach managed under a private foundation. It should be noted that overall there has been a significant improvement and appreciation of the conditions and types of equipment available, promoting the qualification of these spaces for wider use, with better access conditions, security, and associated services. There is a concern for all these spaces with the issues related to the disposal of garbage and recycling dumps, with the conditions that allow the attendance of public with reduced mobility, for which access and ramps that allow to enjoy the river beach, the existence of recreation areas associated with specific areas for fire, food preparation, and clean water access. In all fluvial beaches, there are identified parking areas, with non-pedestrian access to the beach, very conditioned or only possible by bicycle. It should be noted that in more than $66 \%$ of beaches there are camping areas (integrated or adjacent), allowing the overnight stay, and thus conditioning the setting of tents in the specific river beach area (Figure 3). 


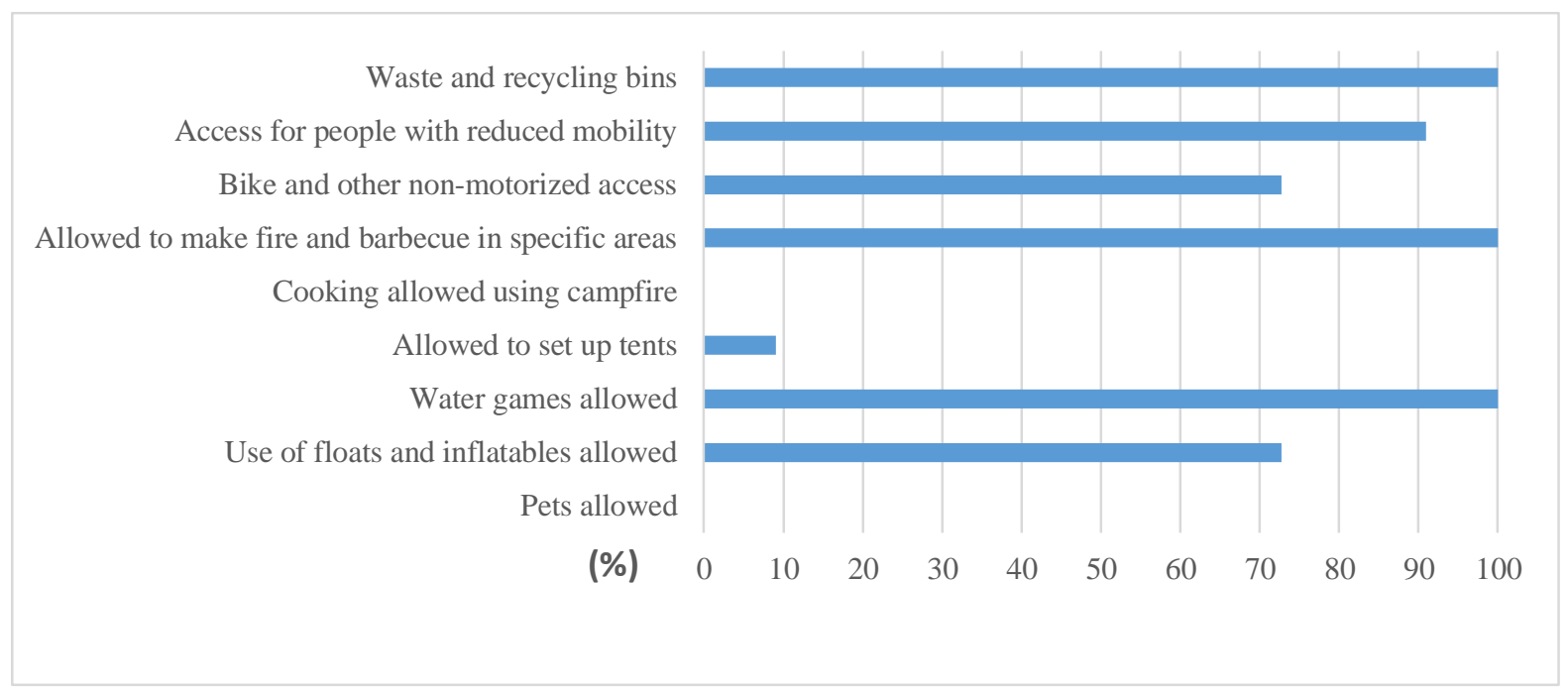

Fig 3. Features of river beaches: access and constraints. Source: survey on river beach management/concessionaires

There has been an effective concern for signalling the different spaces associated with river beaches, leading to investments and the development of means that enable better access, identification of different beach areas and functions, existing services, rules, and hours of operation and information about the water quality. In this context, there are still some gaps in beaches, related to the signalling/identification of activities not allowed, danger zone signalling, as well as the provision of proximity services and local heritage (Figure 4).

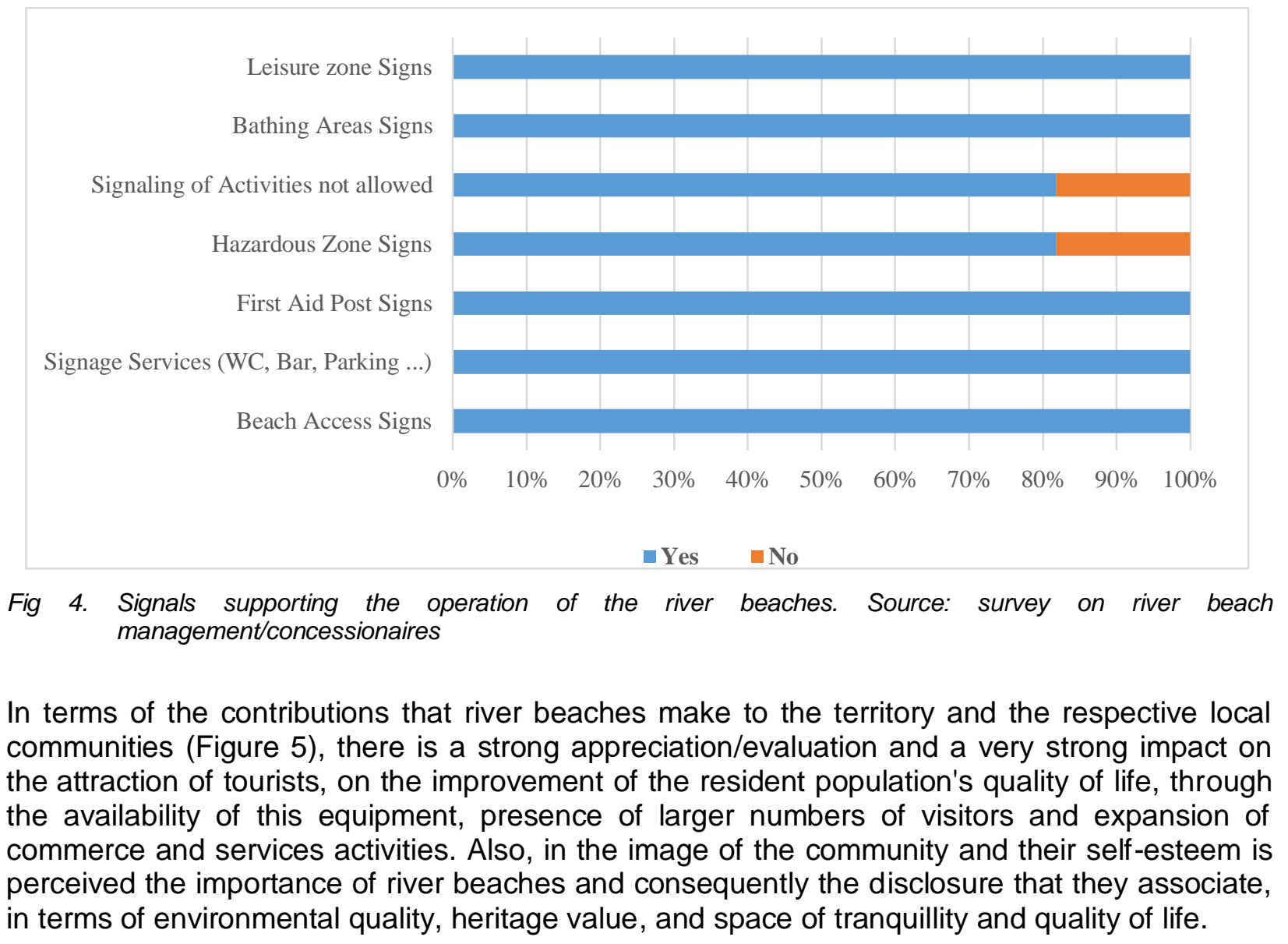


In the support coming from the Municipality

In enhancing local water resources

In the promotion of events and festivities

In encouraging economic activities

In stimulating tourist attraction

In quality of life of resident population

In the image of the community and its self-esteem

- Very weak $\quad$ W Weak
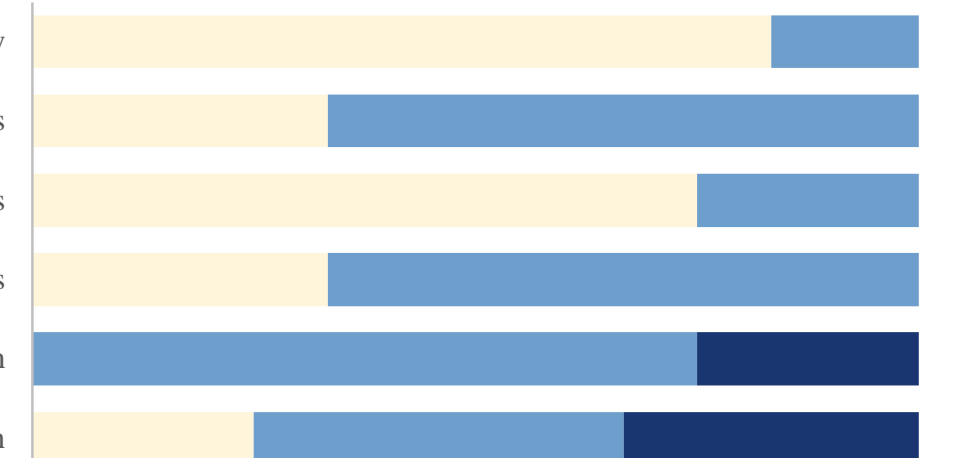

\section{西}
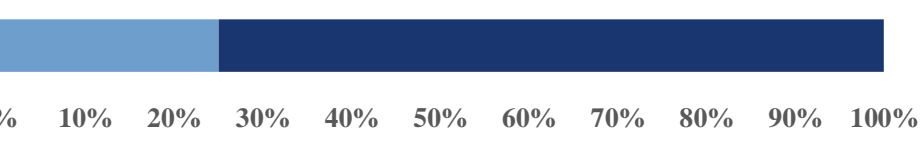

Satisfactory $\quad$ Strong $\quad$ Very strong

Fig 5. Fluvial beaches contributions to the local community in Serra da Estrela. Source: Survey on river beach management/concessionaires

It is an opportunity for economic development, and especially for the summer season, whose competitiveness will be determined by the appreciation of the advantages of the territory (real or perceived) and its differentiation (motivation for difference). It is noteworthy that in addition to bathing practices, allow a large number of aquatic activities, with different intensities and practitioners, ranging from sport fishing, canoeing, paddle, rafting among others.

Overall, they found a very important assessment of the beaches for the tourist appreciation of the Serra da Estrela destination, for attracting tourists to the region and for the well-being of local communities (Table 3). The dissemination of these tourist facilities, their setting in contexts of relevant natural space, and their contribution to minimizing the seasonal attraction effect of the region, related to snow and adventure sports, contribute to their valuation as a tourist asset, to promote the target and create differentiated products. There is a recognition of the importance of river beaches as a tourist resource to enhance, broadening the interaction with local heritage and communities, boosting new business, while constituting as a social responsibility for water quality control, activities developed on the river resource and adjacent areas.

The specific, material and immaterial (biophysical, social, cultural, economic, among others) characteristics of certain places and regions are therefore considered as constitutive elements of their identity. It is these characteristics that give regions originality and uniqueness, which distinguish them from other territories, and make them competitive. To empower object tourism, it is necessary to approach and coordinate with the local population, which needs to be given an understanding of the importance of water tourism in the environment and actively participate in tourism activities (Fachrudin \& Lubis, 2016).

Tab 3. Evaluation of the importance of fluvial beaches for the community and destination (assessments of importance according to their impact). Source: Survey on river beach management/concessionaires

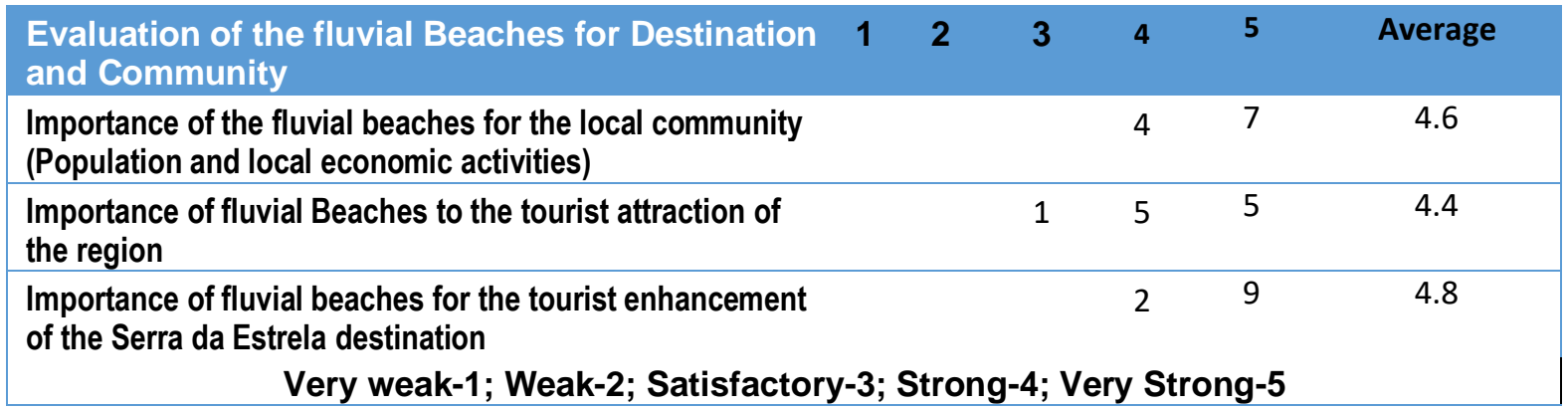




\section{Management and appreciation of inland waters: contributions of river beaches to local communities}

Water, as well as associated aquatic and terrestrial ecosystems, tends to be subject to multiple uses by a set of users with widely differing and sometimes conflicting interests. In their appropriation, the social, economic, and environmental interests tend to be divergent, implying the existence of principles and guidelines that promote their proper regulation, establishing limits and conditions to the developed practices and uses.

In parallel with the increase in water consumption by various activities and economic sectors, there has been a growing recognition of the value of wetlands and surface waters for tourism and leisure activities (Costa, 2010; Ferreira \& Guerreiro de Brito 2009), which record new searches, in particular associated with its bathing, sporting and recreational potential. The great diversity of the water environments, i.e. rivers, streams, lakes, estuaries, beaches, coastlines, marshes, small-islands, wetlands offer specific opportunities for tourism and sport activities, with a multitude of water-based activities for different age categories, education levels and personal preferences (Morar \& Pop, 2016, p. 251)

In this context, it is important to promote the enjoyment of water lines and surfaces in the interior regions, the enhancement of rivers, dams, and their banks, in a strategy of territorial and tourism development. It should foster the well-being of local communities, generate economic value for the region, with concerns for the preservation of ecosystems, water quality, and landscape (Costa, 2010; Folgado-Fernández, 2019). The multi secular relations that rivers have established with the territory they travel and with the riverside communities make them an appreciable environmental, economic, and heritage resource. (Moreira, 2018)

Local communities must have a growing involvement in water-based tourism activities, proactive and enterprising intervention, stimulating these activities, and at the same time having a responsible civic attitude, capable of controlling and alerting to situations of incorrect use or practice. Recognizing that the provision of support equipment and services serves to improve the quality of life and economy of local populations (Poedjiotami, 2008).

These tourism and leisure activities supported by local water resources have a socio-economic and cultural impact, as follows:

- Increase in hotel and restaurant services;

- Encouraging activities of animation and sport;

- Commercial increment associated with recreational and sports activities;

- Increased demand for personal goods and services;

- Encouraging cultural encounters between tourists and residents;

- Infrastructure development and enhancing local welfare;

- Exchange of experiences and knowledge sharing, among others.

The direct involvement of the local population in the development and promotion of a tourist attraction is crucial for the recognition of collective interest, opportunities to emerge, and participation in decision making. (Cole \& Ferguson, 2015; Folgado-Fernandez et al., 2019). Also, direct contact and interaction with tourism stakeholders are relevant. Given the small scale and fragmentation of business in rural areas and the individual constraints of entrepreneurs to promote their activities properly, integrated management and planning are necessary. In this context, building partnerships and developing joint marketing actions and strategies can reduce the isolation of small businesses, allowing resources to be used more effectively (Rodrigues \& Rodrigues, 2007, p. 37). It is considered that this can be a key to the success of tourism development in rural areas, promoting different recreational and cultural experiences, in a context of significant environmental value.

Because water resources such as rivers, lakes or channels are elements that unite different territories/municipalities and support joint activities, they should be important elements of cooperation for the realization of projects and inter-municipal collaboration, promoting synergistic initiatives between entities, promoting the environmental preservation, creation of new uses, 
heritage recovery and income generation. Thus, the tourist use of water resources in rural areas, particularly framed on river beaches, is a true opportunity for local development, enhancing the economy and well-being of communities. It is certainly advantageous a strategy of network articulation of promotion and cooperation in the destination, enhancing different recreational spaces and with different natural frameworks and uses, projecting the region and the business developed. (Cole \& Ferguson, 2015; Gouveia, 2009). These links enable forces to join forces that, when combined with collective action and joint promotion strategies, reduce isolation, fostering more effective resource use, and social well-being. One of the peculiarities associated with river tourism is the possibility of a combination of the aquatic environment with the terrestrial environment, through walks, sports activities, leisure activities, visits to villages, monuments, craftsmen, participation in gastronomic experiences, with their own local identities.

The enhancement of rivers in Portugal is part of the fluvial beach appreciation Program launched on April 4, 1994 (MA, 1997), constituting an important reference for the safeguarding and enhancement of some inland waters, namely it's riverside areas and its cultural heritage., providing them with bathing and leisure spaces; road access and car parks; pedestrian access; signalling; of information; basic infrastructure and equipment networks, offering a range of beach support services and providing a variety of activities, including sports, swimming, fishing, windsurfing, water skiing, and boating (Moreira, 2018).

The creation of river beaches on natural and or artificial water levels in the interior of Portugal, as exemplified by the set of beaches in the Estrela geopark territory, has allowed several valuations in terms of:

- Environmental, requiring regular maintenance and control of water quality and cleaning of banks and accesses;

- Landscape, enhancing the natural areas and promoting equipment and informative signs about the place and its sensitivity;

- Heritage, conserving hydraulic equipment such as mills, watermills, weirs and promoting the connection with the community and its cultural manifestations;

- Security, ensuring protection service, support and help to users;

- Economy, service generation, and increased trade activities associated with local products.

The measures designated in the POA as "conservation and enhancement of natural heritage and improvement of environmental quality" included "regularization and ordering of water lines and other natural areas", where projects for the construction and enhancement of river beaches and the recovery, regularization, and river and stream bank planning were approved. Investments made in the protection of water resources have improved the quality of Portuguese watercourses, thus allowing them to value their banks for bathing use.

The development of river beaches was done through the creation of access, parking, support facilities such as restrooms and kiosks selling food and beverages, and lifeguard surveillance of the beaches. The result was the creation and valorisation of fluvial beaches, which represent a high importance in the process of sustainable development of regions with good tourism potential (Goldstein, 2011). These investments have allowed the number of river beaches to be appreciable in Portugal, an offer that emerges as an alternative to the sun and sea tourism product that benefits from a very mass demand. Santos and Cunha (2008) have noted that the intervention of local authorities, sometimes in isolation, sometimes in conjunction with private initiative, has allowed the enhancement of inland riverside areas where the landscape is combined with aquatic playfulness. Buhalis $(2000)$ stresses that destination can be considered as a combination of all locally sourced products, services, and experiences, such that destination management is challenging given the variety of actors involved in the development and production of tourism products.

It can be said that tourism around river beaches is developed sustainably, when it also supports the culture, the characteristics of the local community and the traditional economy, as its area of influence increases as other tourism products are identified, other added value that the territory can offer and make it distinct, increasing the regional attractiveness and as a consequence 
the number of tourists and their time in the region. Thus, the Serra da Estrela destination is now more diversified and qualified, in which the water resource gains expression, as a means of tourism and leisure, promoting new opportunities for local communities, as equipment and resource for the expansion of trade activities and services.

\section{Conclusions}

Tourism in the inland and particular mountain regions is an opportunity to promote local dynamism, a possibility for economic development, and the reversal of demographic trends. In this sense, the advantages of the interior regions are its endogenous resources, constituted among others by the natural heritage (landscape, water resources, natural areas of ecological importance, geology, forest, among others), the cultural heritage (buildings, traditions, festivities, handicrafts, gastronomy, among others) and the historical and architectural heritage that form its territorial identity. The surface water resources (rivers, lakes, reservoirs, dams, marshes) and the practices associated with them, established relationships with the territory and with the riverside communities that make them a relevant resource.

The diversity of practices and activities that allow development is appreciable, as well as the set of elements that are associated with them and that, must be activated for the benefit of communities and tourism. River tourism can greatly contribute to this activation. In this context, the processes of valorisation of water resources and their qualification for different tourism, leisure, and sport practices, make it possible to increase the attractiveness of the inland areas and enhance the well-being of the local communities and the economic activities to be developed. The expansion that tourism has been experiencing in recent decades has required significant changes in the way business is run, including touristic destinations. Involving public and private leaders in the destination management process can lead to more sustainable tourism development, making it more attractive and competitive. We are faced with a combination of products, services and experiences provided locally, which, given the variety of actors involved in the development of tourism products, managing the destination is a complex and permanent challenge.

In Estrela Geopark territory there is a growing appreciation and adaptation of rivers and lagoons to river beaches, qualifying the destination, enhancing a valuable image for those visiting the region, and for local communities. The valorisation promoted, in particular by the parish councils, provides the region with attractive bathing spaces, providing recreational and recreational activities, particularly in the summertime. The natural characteristics, the quality of the waters, and the present heritage make it possible to strengthen this offer and to extend it in a management that provides a growing connection with local communities and offers that can be promoted in an integrated way.

The growth of river tourism and leisure activities, particularly active in inland waters, is currently relevant, which advises that inventories of the potential held should be invented, so that the existing and potential suppliers can be known and monitored to better manage the different markets looking for this destination. There is a recognition of the potential of river resources and their capacity to meet demand, by populations and rulers, which embodies arguments to enhance the image of destiny, the development of projects to qualify surface waters and their functions and uses.

In future research, it will be relevant to know the perception of the users of this equipment and its motivations, as well as to evaluate its potential and effective demand. Economic sustainability, given the investments this equipment requires, raises the reflection on the cost of use/utilisation and the determination of value, equating the effects on the demand for residents and nonresidents.

In this context, a platform should be developed to support the management of these spaces, allowing easy interaction with the entities that exploit them, in the sense of adequate control and monitoring, qualifying services and equipment, and establishing safety references. More inclusive and collaborative development initiatives for the destination that can reduce power imbalances 
between different tourism actors create cooperative relationships that strengthen the Serra da Estrela region and provide greater economic and environmental sustainability.

\section{Academic references}

[1] Brito-Henriques, E., Sarmento, J. \& Lousada, M. A. (2010). When water meets tourism: An introduction. In Brito-Henriques, E., Sarmento, J. \& Lousada, M. A. eds., Water and tourism. Resources management, planning and sustainability (pp. 13-33). Lisboa: Universidade de Lisboa.

[2] Buhalis, D. (2000). Marketing the competitive destination of the future. Tourism Management 21(1), 97-116. DOI: 10.1016/S0261-5177(99)00095-3.

[3] Cavaco, C. \& Simões, J. (1998). Água, desenvolvimento e bem-estar. Lisboa: MADRP.

[4] Cavaco, C. (2010). Água doce: Agricultura versus lazeres e turismo. In Brito-Henriques, E., Sarmento, J. \& Lousada, M. A., eds.), Water and tourism. Resources management, planning and sustainability (pp. 223-259). Lisboa: Universidade de Lisboa.

[5] Cole, S. \& Ferguson, L. (2015). Towards a gendered political economy of water and tourism. Tourism Geographies 17(4), 511-528. DOI: 10.1080/14616688.2015.1065509.

[6] Costa, C. (2010). O turismo e a água. In À beira da água (pp. 261-295). Coimbra: Comissão de Coordenação e Desenvolvimento Regional do Centro.

[7] Fachrudin, H. T. \& Lubis, M. D. (2016). Planning for Riverside Area as Water Tourism Destination to Improve Quality of Life Local Residents, Case Study: Batuan - Sikambing River, Medan, Indonesia Procedia - Social and Behavioral Sciences 234, 434-441. DOI: 10.1016/j.sbspro.2016.10.261.

[8] Fernandes, S. (2003). Contributo para a Requalificação Biofísica da Praia Fluvial da Valeta (Arco de Valdevez) [final report]. Instituto Politécnico de Viana do Castelo. Escola Superior Agrária de Ponte de Lima.

[9] Ferreira, M. T. \& Ferreira De Brito, A. (2009). Águas interiores supericiais. In Pereira, H., Domingos, T., Vicente, L. \& Proença, V., eds, Ecossistemas e Bem-Estar Humano em Portugal (pp. 341-380). Lisboa: Escolar Editora.

[10] Folgado-Fernández, J., Di-Clemente, E., Hernández-Mogollón, J. \& Campón-Cerro, A. (2019). Water Tourism: A New Strategy for the Sustainable Management of Water-Based Ecosystems and Landscapes in Extremadura (Spain). Land 81(1), 2. DOI: $10.3390 /$ land8010002.

[11] García González, L. (2004). Agua y turismo. Nuevos usos de los recursos hídricos en la Península Ibérica. Enfoque integral. Boletín De La Asociación De Geógrafos Españoles 37, 239-255.

[12] Goldstein, S. (2011). Caracterização ambiental de praias fluviais de Portugal Continental [master thesis], Lisboa: Universidade de Lisboa.

[13] Gouveia, V. (2009). Contributo das praias fluviais para o desenvolvimento regional: a rede de praias fluviais do pinhal interior [master thesis]. Lisboa: Universidade Nova de Lisboa.

[14] Grössling, S., Hall, M. \& Scott, D. (2015). Tourism and Water. Bristol: Channel View Publications.

[15] Hall, C. \& Härkönen, T. (2006). Lake tourism: an introduction to lacustrine tourism systems. In Hall, C. M. \& Härkönen, T., eds., Lake Tourism: An Integrated Approach to Lacustrine Tourism Systems (pp. 3-26). Clevedon: Channel View Publications.

[16] Jennings, G. (2007). Water-Based Tourism, Sport, Leisure, and Recreation Experiences, Oxford: Butterworth-Heinemann. 
[17] La Vanchy, G. T. (2017). When wells run dry: Water and tourism in Nicaragua. Annals of Tourism Research 64, 37-50. DOI: 10.1016/j.annals.2017.02.006.

[18] Morar, C. \& Pop, A. C. (2016). Water, Tourism and Sport. A conceptual approach, GeoJournal of Tourism and Geosites 18(2), 249-258.

[19] Moreira, C. \& Santos, N. (2010). New opportunities for water environments: River tourism and water leisure activities. In Brito-Henriques, E., Sarmento, J. \& Lousada, M. A., eds., Water and tourism. Resources management, planning and sustainability (pp. 147-168). Lisboa: Universidade de Lisboa.

[20] Moreira, C. \& Santos, N. (2016). Turismo fluvial em portugal continental: oferta e potencialidades/river tourism in portugal: touristic offer and potentials. In Nunes, A. et al., eds., Territórios de Água | Water Territories (pp. 255-271). Coimbra: Universidade de Coimbra.

[21] Moreira, C. (2011). Ambientes aquáticos não marítimos no Baixo Mondego: Margens para a recreação, o lazer e o turismo. In Santos, N. \& Cunha, L., eds., Trunfos de uma geografia activa: Desenvolvimento local, ambiente, ordenamento e tecnologia (pp. 149-158). Coimbra: University of Coimbra.

[22] Moreira, C. (2012). Lazer, animação turística e desenvolvimento local. In Jacinto R., ed., Iberografias, 19 - Patrimónios, territórios e turismo cultural: Recursos, estratégias e práticas (pp. 77-103). Lisboa: Âncora Editora.

[23] Moreira, C. (2018). Turismo fluvial, lazeres em águas interiores e desenvolvimento local e regional/River tourism, leisure in inland waterways and local and regional development. Cadernos de Geografia, 18, 55-67. DOI: 10.14195/0871-1623_38_4.

[24] Moreira, I., Ferreira, M., Cortes, R., Almeida, P. \& Pinto, P. \& Raposo de Almeida, P. (2002). Ecossistemas Aquáticos e Ribeirinhos. Ecologia, Gestão, Conservação. Lisboa: Edições do Instituto da Água.

[25] Peixoto, P. (2016). Os usos sociais dos rios. In Peixoto, P. \& Cardielos, J. P., eds., A água como património. Experiências de requalificação das cidades com água e das paisagens fluviais (pp. 57-70). Coimbra: University of Coimbra.

[26] Poedjioetami, E. (2008). Penataan ulang kawasan bantaran sungai dengan menghadirkan sentra ekonomi dan rekreasi kota, studi kasus kawasan Dinoyo Tenun, Surabaya. Jurnal Rekayasa Perencanaan 4(3), 1-11.

[27] Prideaux, B., Tomothy, D. \& Cooper, M. (2009). River Tourism, Wallingford: CAB International.

[28] Rodrigues, A. \& Rodrigues, A. (2007). Rede Europeia de Turismo de Aldeia, um Caso de Inovação em Turismo Rural. Congresso Internacional de Turismo - Leiria e Oeste.

[29] Santos, N. \& Cunha, L. (2008). Novas oportunidades para o espaço rural. Análise exploratória no Centro de Portugal. In Santos, N. \& Gama, A., eds., Lazer: Da libertação do tempo à conquista das práticas (pp. 209-225). Coimbra: University of Coimbra.

[30] Santos, N. (2012). A gestão das bacias hidrográficas e a valorização turística dos ambientes fluviais: O rio Mondego. Revista Geonorte 4(4), 210-219.

[31] Saraiva, M. (1999). O rio como paisagem: Gestão de corredores fluviais no quadro do ordenamento do território. Lisboa: Fundação Calouste Gulbenkian.

[32] Vaz, B. (2008). Contributos para a Avaliação e Gestão de Praias: A Importância da Percepção dos seus Utilizadores [master thesis]. Lisboa: Universidade Nova de Lisboa.

[33] Violier, P. (1993). Le tourisme fluvial dans la région Pays de la Loire et la dynamique des espaces et sociétés rurales. Norois 40(159), 371-386. DOI: 10.3406/noroi.1993.6493. 
[34] World Tourism Organization (2016). Mekong River-based Tourism Product Development, UNWTO, Madrid.

[35] Mlnistério do Ambiente (MA) (1997). Programa de Valorização das Praias Fluviais. Lisboa:MA, SERN e IA. 